\title{
DETERMINANTS ON AUDIT QUALITY OF CITY INSPECTORATES IN SOUTH SULAWESI PROVINCE
}

\author{
Usman Asri*, Nagu Nadhira, Syahrir, Sundari Sri \\ Accounting Study Program, Faculty of Economics and Business, \\ University of Hasanuddin, Indonesia \\ *E-mail: asriusman08@yahoo.com
}

\begin{abstract}
This study aims to identify and analyze the effect of leadership style on self-efficacy, the effect of leadership style on emotional exhaustion; self-efficacy influences the emotional exhaustion, and emotional exhaustion on audit quality. This study uses a quantitative approach. The population in this study was all auditors in city inspectorates in South Sulawesi Province, Indonesia. The sampling technique used in this research is purposive sampling where the sampling is based on the consideration or criteria in accordance with the purpose of research. These research data will be obtained by filling out a questionnaires, and direct interviews with respondents. Data are collected through questionnaires and interviews, and are analyzed using quantitative and descriptive analysis techniques.
\end{abstract}

\section{KEY WORDS}

Self-efficacy, leadership style, emotional exhaustion, quality, audit.

The quality of work of auditors relates to the quality of expertise, timeliness of completion of the work, the sufficiency of evidence examination and independence attitude towards clients. According to the regulations of the Minister of State for Administrative Reform No.Per / 05 / M.PAN / 03/2008 on Auditing Standards Government Internal Supervisory Apparatus (APIP) audit quality is affected by the membership stating that the auditor should have the knowledge, skills and other competencies needed to carry out their responsibilities to the criteria the auditor must have a minimum education level Starata one (S1), with competence in auditing, accounting, administration, communications and has been a certified auditor and follow the functional education and continuous professional training.

Adhere to established standards is an obligation that must be carried auditors in their duties, but the reality on the ground auditor doing a lot of deviation on auditing standards and code of conduct, offenses committed by auditors in the examination can be categorized as a deviation in the audit, such as completing audit assignments without through prosudur audit that has been set, changing prosudur previously been defined in the audit field, do not collect sufficient evidence on matters that material, process the data with inaccurate and reported the time of the audit with the total time is shorter than the actual time

Audit quality produced by city inspectorates in South Sulawesi is still in the spotlight. Based on the results of BPK first half of 2014 there were 14 financial statements of local government in South Sulawesi found143 cases of irregularities. Factors causing low quality of audit inspectorate officials is the lack of education and training apparatus functional in the field of supervision, lack of attention on the work, theirsaturation in doing the work that needs to be rotation or change of work regularly and their work unit causing mutations among experienced officers replaced by less experienced and less attention to improving incentives which refer to the changing needs of life erratic.

Empirical evidence from research shows that there are behavioral deviations encountered by the auditor in order to fulfill the responsibilities of his profession. The contributing factor is the individual's internal auditor factors such as self-efficacy, emotional exhaustion and external factor is the leadership style. Internal and external factors can cause irregularities alleged by the auditors in carrying out its duties, it is because the auditor with low self-efficacy, emotional exhaustion unstable and uncommunicative leadership style will work not according to predetermined rules. 
According to Bandura (1997) self-efficacy is a person's belief that he can master the situation and produce results (outcomes) were positive. Self-efficacy is an individual assessment of confidence in his ability to perform tasks that get results as expected.

Saturation in doing the job can lead to emotional exhaustion (emotional exhaustion). According to Cherniss (1980), emotional exhaustion as a response to excessive stress or as a result of dissatisfaction and boredom at work. Source emotional exhaustion can occur in individuals who have a perfectionist personality tendencies or demand excellence in every job (Caputo, 1991).

Self-efficacy and emotional fatigue is influenced by the style of leadership. Leadership create a work environment where individuals are motivated, inspired, challenged, and feel successful. A leader who easily communicate make employees have a say in resource allocation decisions and emotional exhaustion experienced lowered. Conversely, when employees are faced with a demand that is not fixed and notice the lack of their influence on the allocation of resources, they become frustrated, disappointed and dissatisfied. This shows that the leadership has a direct and indirect impact on job satisfaction. Indirect impact is reflected by emotional exhaustion.

\section{LITERATURE REVIEW}

Contingency Theory. Contingency theory approach to identify optimal forms of leadership under different operating conditions and try to explain how the leadership operating procedures. This approach is based on the premise that there is no universally leadership is always appropriate to be applied to any organization, but this depends on factors condition or situation that exists in the organization. Tthrough Home Visits contingency view that effective groups depend on the match between the leader's style that interacts with subordinate so that the situation becomes controllers and influence the leaders.

Theory of Motivation. Motivation is the driving force of one's heart to do or achieve something of interest, or can be regarded as a plan or desire for success and avoid failure of life. The basic principle of motivation is the level of ability (ability) and motivation of individuals who can be said that the performance of a person or group is a function of its ability and motivation. According to these principles there is no task that can be performed well without supported by the ability to carry it out. The ability of an individual talents / groups to perform tasks related to the purpose, but the ability is not sufficient to ensure the achievement of the best performance. The individual must have the desire (motivation) to achieve the best performance.

Resources Conservation Theory (COR). Resources Conservation Theory first popularized by Stevan Hobfoll (1988) which explains about the concept of human experience stress due to aging. This theory does not apply to the stress caused by the loss, investment, profits and trauma. Resources Conservation Theory is essentially a model for understanding the stress which this theory is not assume that people develop when they protect, acquire, maintain and conserve resources. The resources are defined as something valuable that meet the needs of an individual's life.

Self-efficacy. Self-efficacy is one of the self-regulating ability of the individual, the concept of self-efficacy was first proposed by Bandura. Self-efficacy refers to the perception of the individual's ability to organize and implement actions to display certain skills, (Bandura 1997; 391). Pervin (1997) gives a statement reinforcing Bandura above. Pervin states that self-efficacy is the perceived ability to shape the behavior relevant to the task or special circumstances, Pervin (1997) cited by (Smet 1994: 189).

Emotional exhaustion. Fatigue is a protective mechanism the body avoid further damage resulting in the recovery after the break. In this study, emotional exhaustion is "feeling which a person depressed and exhausted because of a job" (Maslach and Jackson 1981; 101). It often occurs when employees provide services, (Cordes and Dougherty, 1993). Professional services required to promote the welfare of their clients request which contains the diversity of cognitive, emotional and human behavior. Actually, the service workers on a 
regular basis often experience negative reactions of consumers and the verbal attack, it can make them faster to feel emotional exhaustion (Cordes and Dougherty, 1993).

Quality Audit. DeAngello (1981) defines quality audit (audit quality) as "market assess the possibility that the auditor will give a) the discovery of a breach in the client's accounting system; and b) any irregularity in the recording. "In the public sector, GAO (1986) defines quality audit is compliance with professional standards and according to the terms of the agreement, which must be considered. Another notion that is used in connection with studies on audit quality is an analysis of the quality in terms of regulations made by government officials. Then the approach of three Schroeder et.al (1986) and Carcello et al (1992) identified an association between the attributes of audit quality and audit quality perceived.

Empirical Overview. Research relating to the quality of leadership has long been investigated and has been done, one of the researchers who conducted the research among others Thorlakson and Murray (1998), which proves that there is a relationship that gained the leadership qualities of an organization or leader of the organization will be able to lead the organization toward more and can develop the potential of the organization.

Research conducted by Mulki et al., (2006) titled "Emotional exhaustion and organizational deviance: Can the right job and a leader's style of make a difference?". This study describes the emotional exhaustion and irregularities organization received more attention because of the negative effects they provide in a loss of productivity of the business sector, decreased job satisfaction, organizational commitment is low, and decreased performance. In this study, focused on the combination of the impact of leadership style and precise work of someone against emotional exhaustion using a sample of workers who provide health and social services in a metropolitan city.

Sigiro and Cahyono (2005) conducted a study of non-production employees of PT Kusumahadi Santoso Surakarta. The purpose of research is to know the difference of job satisfaction in terms of locus of control, personality type and self efficacy. The results of his research is that the external experience high job satisfaction compared with the internal. Then the person who has type A personality experienced higher job satisfaction than those with personality type B. Meanwhile, people who have high self-efficacy tend to have higher job satisfaction than those who have low self-efficacy.

\section{CONCEPTUAL FRAMEWORK AND HYPOTHESES}

Conceptual Framework Research. The conceptual framework of this research is based on the incorporation, development, and modification of some of the concepts and theories. The variables used in this study refers to the theories of motivation, contingency theory and Resources Conservation Theory (COR), as well as other support such a theory of selfefficacy theory, the theory of emotional exhaustion and audit quality.

This study also draws on resources Conservation theory to explore the impact of leadership style and self efficacy on emotional exhaustion. Theory of Conservation Resources shows that emotional exhaustion arises when workers noticed the lack of resources to do their job, (Halbesleben and Buckley, 2004; Janssent et al, (2004). When the workers / employees know that resources are not sufficient to meet the demand for jobs or when additional support personnel provide not the desired outcome emotional exhaustion can appear (Wright and Hofboll, 2004).

Based on the above, then formed a research model that is expected will be a guideline for solving the problems presented in this paper. The model in this study was the effect of leadership style on self-efficacy, emotional exhaustion and their impact on audit quality. The theoretical framework proposed in this study is seen from Figure 1. 


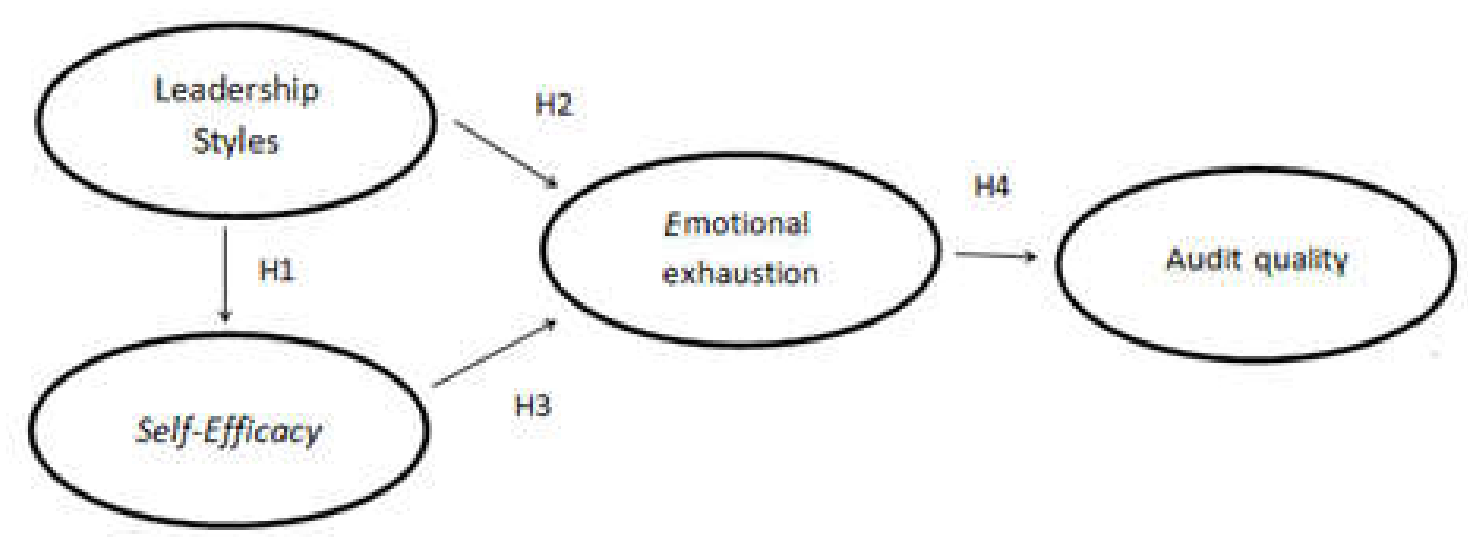

Figure 1 - The Theoretical Framework

The relationship between the variables and the formulation of hypotheses. Based on the formulation of the problem and the conceptual framework that is built, it can be stated logic and formulation of hypotheses as to the following description.

Leadership Style and Self-Efficacy. Leadership style, according to Luthan (2002), "...deals with the way leaders influence followers". Style of leadership with regard to the ways used by managers to influence subordinates. Leadership styles are norms of behavior that used a manager when it affects the behavior of his subordinates.

Self-efficacy is one of the self-regulatory capacity individu.Self-efficacy refers to the perception of the individual's ability to organize and implement action to display a particular skill, Bandura (1997: 391). Pervin et.al (1997) gives a statement reinforcing Bandura above. Pervin states that self-efficacy is the perceived ability to shape the behavior relevant to the task or special circumstances (Smet, 1994: 189-190).

Avolio et al.'s research (2004) concurred with the research Azwar conclude that participative leadership style managers play a very important role in creating confidence \{self-efficacy) for employees. How does a leader influence individuals to behave, behave, and motivate yourself to be one source of power of the individual in the emerging selfefficacy, thus also described by Wicaksono (2008) self-efficacy is an element that can change the vibration of ordinary thinking; of the finite mind, into a form equivalent into the spiritual corridor; and is the basis of all "miracles", as well as a mystery that can not be analyzed by means of science. then:

Hypothesis 1: The leadership style positive effect on self-efficacy.

Leadership Style and Emotional Exhaustion. Style of leadership with regard to the attitudes and behavior of workers; particularly with respect to the perception of the role, job anxiety, job satisfaction, the tendency to stop, and reciprocal Jones. (1996). Leadership styles have a direct influence on attitudes such as job satisfaction but also has an indirect impact on other variables (Anderson and Huang, 2005; Ruyter et al. 2001)

An organizational climate that is suffused with the goal of leadership path changing worker beliefs about their capabilities, minimizing the lack of aid and a loss of confidence, Abraham (1998), thereby decreasing emotional exhaustion. COR theory states that the leadership will produce a high emotional exhaustion since you feel less needed in the absence of a sound or control the resources available to meet demand fulfillment of work (Wright and Hofboll 2004). Results of research Mulki et al. (2006) concluded that leadership style is a key factor in reducing emotional exhaustion. Then:

Hypothesis 2: The leadership style negative effect on emotional exhaustion.

Self-Efficacy and Emotional Exhaustion. Self-Efficacy high performance and contribute to the reduction of the emotional exhaustion. Besides self-efficacy also benefit effectively to the individual to integrate, and use the information to improve the clarity of the role and performance ((Brown et.al 2001). Research Salanova et al, (2002) found no support for the role of moderator Self Efficacy against employees who have high emotional exhaustion and research Grau et al. (2001). Jex et al. (2001) Self Efficacy show that provide support for the 
role of moderator of the employees who have high emotional exhaustion. the results Bandura \& Locke (2003) concludes that individuals with self-efficacy height of more able to cope with threatening situations and difficult than individuals with self-efficacy is low, therefore an individual with self-efficacy height did not experience emotional exhaustion on improving the performance of higher, because people are trying to achieve the goal of employment compared with individuals with low self efficacy. Thus:

Hypothesis 3: Self-efficacy negative effect on emotional exhaustion.

Emotional Exhaustion on Audit Quality. Emotional fatigue resulting from a lack of leadership directives that are more directly linked to the organization rather than between colleagues. This is because workers are often viewed supervisor transform companies that often affect their lives (Strutton et al. 1993). Thus, both the supervisor and the lack of action measures that affect worker attitudes (job satisfaction and organizational commitment) and organizational behavior. and workers who are not satisfied because of the onset of emotional exhaustion on the job often misbehaves towards the organization, otherwise when the worker happy with his work, they reciprocate by helping the organization achieve its objectives (Judge et al., 2006).

Auditor as a profession that provides assurance about the information services of the audit report to the public are required to have knowledge and accounting skills and personal qualities enough. Personal qualities will be reflected in the behavior of his profession. Professional conduct of auditors can be realized in the form of audit irregularities avoiding behavior which in this study is categorized as one of the aberrations of the organization. Behavior audit irregularities in question is behavior that deviates from the auditor auditing standards in conducting audits that can degrade the quality of audit (Harini et al., 2010; 11). Based on these descriptions, then:

Hypothesis 4: Fatigue emotional impact directly and indirectly on audit quality.

\section{METHODS OF RESEARCH}

Research Approach. This study uses a quantitative approach. The focus of this study refers to the theories or hypotheses to be tested as the cause of a phenomenon. The phenomenon can be seen in a unit of analysis in this study is the auditor City inspectoratesin South Sulawesi Province. Data collection from respondents was conducted using a questionnaire and through an interview given to the auditor Inspectorate of the district / city in South Sulawesi Province. The time horizon of this study was cross sectional study at a certain time that is carried out from February to August 2016.

Population and Sampling Techniques. The population in this study were all auditors city inspectoratesin South Sulawesi. The sampling technique used in this research is purposive sampling, that the sampling is based on the consideration or criteria in accordance with the purpose of research. Criteria used investigators to determine the sample is the auditor city inspectoratesthat has a fundamental duty and functionin Rule regent / mayor, one of the points of the job description states "implement guidance, inspection, investigation, testing and assessment areas of development, finance and wealth.

Auditor city inspectoratesin South Sulawesi predicted about 620 auditors. Each district / city received / given a questionnaire based on the number of auditors who meet the established criteria, thus there are 620 questionnaires sent / filled by the auditor of the 25 districts / cities in South Sulawesi. Samples were selected in this study is based on questionnaires returned and deserves to be treated as many as 232 auditors.

Data Collection Techniques. These research data will be obtained by filling out a questionnaire, and direct interviews with respondents. Data were collected through questionnaires and interviews is analyzed using quantitative analysis techniques and descriptive.

Test Validity and Reliability:

Test Validity. Azwar (2003: 90) explained that the validity indicates the extent to which a measuring device (instrument) that measure what you want measured. A concept composed of multiple components or variables. If the validity test instrument invented an invalid 
component, it can be said that the components are not consistent with the other components to support a concept.

Test Reliability. Reliability is an index indicating the extent to which a measuring device is reliable or unreliable. If a measuring device is used twice to measure the same symptoms and the measurement results obtained are relatively consistent, the gauge is reliable. In other words, the reliability of the consistency of a gauge in measuring the same symptoms.

Data Analysis Techniques. Based on the framework of research that has been stated previously, data analysis techniques used in this research is Structural Equation Model (Structural Equation Modelling = SEM). The reason why it is used Structural Equation Modelling (SEM) in this study is based on the consideration that, SEM provides a method directly related to their multiple relationships simultaneously at once, so as to provide the efficiency of statistical analysis and SEM has the ability to examine the relationship comprehensively between the variables studied. Besides SEM is very useful in testing a series of mutually dependent relationship between variables simultaneously, ie when one dependent variable can be independent variables in the equation relationship further.

Operational Definition and Measurement:

Leadership style. Leadership style is the pattern of behavior exhibited by that person at the time affects the activity of other people as perceived others. The variables measured in this study is limited to the instruments directive leadership style and supportive leadership style. The indicators used for the two-dimensional variables above using 17 items of questions.

Self-Efficacy. Self-efficacy a belief in one's ability to perform the task. Self efficacy variable was measured with an instrument developed by Jones in 1996 consisting of seven of the questions.

Emotional Exhaustion. Emotional exhaustion experienced by a person is feeling depressed and exhausted because of a job (Maslach and Jackson, 1981: 101). This variable is measured with an instrument developed by Hobfoll $(1988 ; 1989)$ which consists of nine items of questions.

Audit Quality. Audit quality is a test carried out thorough and regular financial statements in assessing the consistency, accuracy and fairness of the application of generally accepted accounting standards

\section{RESULTS AND DISCUSSION}

Descriptive Analysis:

Leadership Styles. In this study, the measured variable is limited to the instruments directive leadership style and supportive leadership style. Perception auditor's leadership style variable for the dimensions of directive leadership style can be interpreted that the respondents rated it good / important, it can be seen from the average value of 4.02 . This means that auditors felt the team leader's involvement in giving assignments, understanding the assignment, deciding task to be done, providing the information required by the team members, and at the time of carrying out the work and give advice in completing the audit assignment. In addition the team leader is also scheduled work team members, maintaining the performance standards defined and team leaders ask team members to comply with the regulations and rules applicable standards.

Furthermore, the auditor's perception of the leadership style variable for the dimensions of supportive leadership style can be interpreted that the respondents rated it good / important, it can be seen from the average value of 3.93. This means that the auditor feels the team leader is a person who is friendly and easy to understand, treat all members are equal with him, paying attention to the progress of work of the team members, also explain how to complete the audit tasks to be performed by members of the team Besides the team leader also do those little things that make the audit team happy to be a member of the audit team, the team leader showing care and concern for the welfare of the team members and team leaders to help make his job so easy to do. 
The average overall of two-dimensional (directive and supportive leadership style) measurement of leadership style is 3.98. This illustrates that the style of leadership in the inspectorate, as measured by the dimensions and with each of the indicators above show leadership styles that can direct and give suppor / auitor support to carry out their duties.

Self Efficacy. Self efficacy variables measured with instruments, which consist of seven the questions. it can be seen that of the 232 people surveyed auditor auditor general perception towards self efficacy variables can be interpreted that the respondents rated it good / important, it can be seen from the average value of 4.22 . This suggests that selfefficacy is already well owned auditors with confidence in their ability to complete the audit work both challenging job or a job that requires the help of facilities and the help of friends.

Emotional Exhaustion. This variable is measured with an instrument that consists of nine items of questions. It can be seen that of the 232 people surveyed auditor general perception of the variables emotional exhaustion can be interpreted that the respondents give enough value, it can be seen from the average value of 2.63. This indicates that the auditor find a job as an auditor simply create emotional exhaustion.

Audit Quality (Y4). Based on the results of the study showed that of the 232 people surveyed auditor general perception auditor to audit quality variables can be interpreted that the respondents give enough value, it can be seen from the average value of 2.61. This suggests that auditors often find and report errors that it finds or it can be said that the quality of audits produced by the auditor Inspectorate of the district / city is still quite good.

Hypothesis testing:

Leadership style and self-efficacy. Leadership style has a significant positive effect on Self Efficacy with $P=0.000>0.05$ with a coefficient of 0634, this coefficient indicates that the style of leadership that will either make self efficacy auditor is getting stronger.

This indicates that the style of leadership that gives direction and support to auditors who carry out the audit work can increase and improve self-efficacy of auditor in completing the work. This finding is consistent with Azwar (1996) self-efficacy is a person's belief that he is capable of performing a specific task well where a person's beliefs to perform certain tasks properly influenced by the style of leadership, attitudes and behavior.

The above results are supported by the fact the field in a directive leadership style that the team leader who usually give advice to members of the audit team for the completion of the audit assignment. Furthermore, to the style of supportive leadership for example team leaders always pay attention to the progress of work of the audit team members, team leader also explains how the completion of audit tasks which must be performed by the audit team members, team leaders also help overcome the problems faced by members of the audit team until the completion of an audit until finish.

This study is in line with the theory of contingency Path goal for leader behavior is acceptable when the auditors looked at the direction and support (supportive) as a source of inspiration and motivation. Support auditor to the leader because of the experience and capacity that is owned by its leader is already quite mature it can be seen from the number of auditors whose age is above 36 years ranges from $46.55 \%$, where the age range have got the confidence as a team leader in a field audit assignment.

Leadership styles and emotional exhaustion. Leadership style no significant influence on the emotional exhaustion with $P=12: 08>0.05$ with a coefficient of 0183 , this coefficient indicates that a good leadership style does not make emotional exhaustion decreased. leadership not significant effect on emotional exhaustion auditor.

This means that the style of leadership that gives direction and support emotional exhaustion auditors carry out their duties in the face and still can happen. This finding is not in line with Ruyter et al., (2001), which states that the style of leadership has a direct influence on attitudes such as job satisfaction but also has an indirect impact on other variables such as emotional exhaustion.

The results of this study indicate that the leadership style does not affect emotional exhaustion. This is supported by the theory of the destination path (path-goal theory), leader behavior is acceptable when employees see it as a source of satisfaction, subordinate to 
actively support leaders as long as he considers that the actions leaders can improve the level of satisfaction with Hughes et al. (1999).

The results mentioned above are supported by the fact the field in a directive leadership style that the team leader always decide what and how to work to do its members, the team leader to schedule work to be done by team members other than the chairman of the team also provide the information necessary for the work of the audit team members but because of the quantity and frequency of audits of a number of SKPD to be covered so much so as to make the members of the audit team was tired with his work as an auditor responsibility. Similarly, in the style of supportive leadership that the team leader is always paying attention to the progress of work of the audit team members, in addition to the head of the team always pay attention and concern for the welfare of members of the team but it still makes team members feel tired in completing the work as an auditor in particular the existing auditor the team members who always expect the result of the occupation have to be perfect (perfect).

Self-efficacy and emotional exhaustion. Self efficacy has a significant negative effect on emotional exhaustion with $P=0.000>0.05$ with a coefficient of -0.468 , these coefficients indicate that self-efficacy is owned by auditors can reduce emotional exhaustion auditor.

This shows that with high confidence that the auditor to do the job can create emotional exhaustion auditor declined to employment faced. These findings are consistent with research conducted by Bandura (1997) concluded that individuals with self-efficacy height of more able to cope with threatening situations and difficult than individuals with self-efficacy is low, therefore an individual with self-efficacy height did not experience emotional fatigue on performance improvement more high, because people are trying to achieve the goal of employment compared with individuals with low self-efficacy.

The results mentioned above are supported by the facts on the ground that the auditor believes can complete any audit work assigned and can perform these tasks well even if the task is complex, especially if supported by a complete facility, this does not make the auditors feel tired of working, no need to deploy all the capacity and power to complete the audit work that is its responsibility. High trust (self Efficacy) Owned by an auditor selected for ability and experience lead as complicated and as much as any audit work encountered can be resolved, so that self-efficacy has an auditor who can lower or eliminate emotional exhaustion caused by the complexity and amount of work faced.

Emotional exhaustion and Audit Quality. Emotional exhaustion direct negative impact is not significant on audit quality of -0.026 , this coefficient indicates that the emotional kelehan does not affect the quality of auditing despite the negative direction.

The test results showed that emotional exhaustion negative direct effect and no significant effect on audit quality. This indicates that the audit team members who experience emotional exhaustion or not experience emotional exhaustion in performing his job does not affect the quality of their audit. This finding is consistent with Barnes (1980), which says there are several factors that affect the level of fatigue include hours of work, the physical condition of the working environment that influence physical comfort, attitude and mental labor is reduced or eliminated as far as possible in order to create favorable working conditions.

The above results are supported by the facts on the ground that the auditors feel pressured to audit work does not make the work of the auditor is qualified or not. The extent and the number of inspection items that must be completed by the auditor with the time that has been scheduled to make auditors vulnerableg experiencing emotional exhaustion, this does not affect the audit work resulting from audit work has become rutinuitas seoranga inspectorate auditor every day.

\section{CONCLUSION AND RECOMMENDATIONS}

Based on the research results, several conclusions can be made:

Leadership style positive effect on self-efficacy, it indicates that the style of leadership that will either make self-efficacy or confidence auditor higher. 
Leadership style has no effect on emotional exhaustion auditor; it shows that good leadership style does not make emotional exhaustion decreased.

Self-efficacy negative effect on emotional exhaustion, it shows that self-efficacy is owned auditor may reduce emotional exhaustion auditor.

Emotional exhaustion significant negative direct effect on audit quality, this indicates that the emotional exhaustion auditor does not affect the quality of auditing despite emotional exhaustion auditor in working low or declining.

Following the above conclusions, several suggestions can be made:

Auditor inspectorate still need training related to management leadership so that the auditor acting as team leader in audits can be more effectively lead their team members to be able to complete audits in lapanngan.

Confidence (self-efficacy) auditors tasks inspectorate to audit needs to be improved with a lot of training related to the duties as auditor.

To avoid emotional fatigue caused due to dense audit in the auditor inspectorate inspectorates need to understand the regulations and code of conduct audits, audit communication, technological mastery and taxation and audit psykologi.

\section{REFERENCES}

1. Abraham, R. 1998 Emotional dissonance in organizations: A conceptualization of consequences, mediators and moderators. Journal Leadership Organization Development 19 (3):137-46.

2. Anderson, R.E., Huang W-R. 2005. Empowering salespeople: Personal, managerial, and organizational perspectives. Psychol Market 23(2):139-59.

3. Avolio, B.J., Zhu, W., Koh, W., Bhatia, P. 2004. Transformational leadership and organizational commitment: Mediating role of psychological empowerment and moderating role of structural distance. Journal Organization Behavior, 25(8):951-68.

4. Azwar, S. 2003. Sikap Manusia: Teori dan Pengukurannya. Edisi Kedua. Yogyakarta: Penerbit Pustaka Pelajar.

5. Bandura, A. 1997. Self-efficacy: the exercise of control. New York: W.H. Freeman/Times Books.

6. Bandura, A. \& Locke, E.A. 2003. Self-efficacy and purpose of negative effects. Journal of Applied Psychology, 88, 87-99.

7. Barnes, R.M. 1980. Motion and Time Study, Design and Measurement of works. Seventh Edition. John Wiley and Sons, New ork.

8. Brown, Stevan P., Ganasan, Shankar and Challagalla, Goutam. 2001. "Self - Efficacy as a Moderator of Information Seeking Effectiveness". Journal of Applied Psychology. Vol. 86. No. 5.

9. Caputo, J. S., 1991. Stress and burnout in library service.Canada : the Oryx Press

10. Carcello, J.V, R.H. Hermanson, and N.T. McGrath. 1992. Audit Quality Attributes : The Perceptions of Audit Partners, prepares and Financial Statement users, Auditing : A journal of Practice \& Theory 11 (Spring) ; 1 - 15

11. Cherniss, C., 1980. Staf burnout : Job stress in human services. Baverly Hills ; Sage Publication.

12. Cooley, C.H. 1930. Sociological Theory and Social Research. New York: Henry Holt and Company.w and an integration of research on job burnout. Academy of Management Review 18, 621-656.

13. Cordes CL, Dougherty TW., 1993, A review and an integration of research on job burnout. Academy of Management Review, 18, 621-656.

14. DeAngelo, L. 1981. Auditor Independence, Low balling and disclosure regulation, journal of Accounting and Economics, Aug $113-127$

15. Gao JP, Chao, DY, and Lin, HX, 1986. "Understanding abiotic stress tolerance mechanisms ; recens studies on stress response in rice. Journal Integrate Biology. 75; 537-553. 
16. Grau, Artis A.B., Walters, J.H., Licata, J.W. 2001; Role Stressor, Service Worker Job Resourcefulness and Job Outcomes : An Empirical Analysis. Journal of Business Research 59, pp 779-791.

17. Halbesleben JRB, Buckley MR, 2004. Burnout in organizational life. J Manage; 30(6):859-79.

18. Harini, Dwi., Agus Wahyudin \& Indah Anisykurlillah. 2010. Analisis Penerimaan Auditor atas Dysfunctional Audit Behavior: Sebuah Pendekatan karakteristik personal auditor. Simposium Nasional Akuntansi XIII Purwokerto

19. Hobfoll, Steven E. The Ecology of stress. Hemisphere; New York 1988

20. Hughes, R.L., Giannett, R.C. \& Curphy, G.J, 1999. Leadership Enchancing the Lessons of Experince. New York; McGraw-Hill Irwin.

21. Janssen PPM, Peeters MCW, Jonge Jd, Houkes I, Tummers GER. 2004. Specific relationships between job demands, job resources and psychological outcomes and the mediating role of negative work-home interference. J Vocat Behav;65(3):411-29.

22. Jex, S. M. P.D. Bliese, S. Buzzell, and J. Primeau. 2001. The Impact og Self Efficacy on Stressors=Strain Relations : Coping Style as an Explanatory Mechanism. Journal of Applied Psychology. Vol. 86 (3), p. $401-409$.

23. Jones, G.R. 1996. Socialization tactics, self efficacy and newcomers adjustments to organizations. Academy of Management Journal, 29. Pp. 262-279..

24. Judge, Timothy A. 2006. Promote ob Satisfaction Through Mental Challenge. The Blackwell Handbook of Principles of Organizational Behavior. Blackwell Publishing: Victoria-Australia

25. Luthans, Fred. 2002. Organizational Behavior, Ninth Edition. Singapore: McGraw-Hill International Editions.

26. Maslach C. \& Jackson S.E., 1981, The measurement of experienced burnout. Journal of Occupational Behavior 2, 99-113.

27. Mulki, J. Prakash, F. Jaramillo, and W.B. Locander 2006. "Effect of Ethical climate and supervisory to trust on sales person's job attitudes and intentions to quit". Journal of Personal Selling and Sales Management. Vol. XXVI. No. 1. Winter, pp. 19-26

28. Pervin, L. A., \& John, O. P. 1997. Personality: Theory and research (7th edition). New York: John Wiley \& Sons, Inc.

29. Ruyter, K., Moorman, L. and Lemmink, J. 2001. Antacendents of commitment and trust in customer-supplier relationships in high technologi markets, Industrial Marketing Management, Vol. 30 No. 3, pp. 271- 86.

30. Salanova, M., Schaufeli, W. B., Llorens, S., Peiro, J, M., \& Grau, R. 2002. Desde el "burnout" al "engamement" : una nueva perspective (From "burnout" to "engagement" : A new Perspective). Revista de Psicologia del Trabajo de las Organizaciones, 16, 117-134.

31. Sigiro dan Cahyono, 2005, Analisis Perbedaan Tingkat Kepuasan Kerja ditinjau dari Locus of Control, Tipe Kepribadian dan Self Efficacy, Jurnal Bisnis dan Manajemen, Vol. 5, No. 2.

32. Smet, B. 1994. Psikologi kesehatan. Jakarta : PT. Gramedia Widiasarana. Indonesia.

33. Stevan Hobfoll. 1988. Resourcce Conservation as community psychology, Kent State University. Jurnal Komunitas Psikologi 21,128-147.

34. Strawser, Robert H, John M, Ivencevich., and Herbert L. Lyon, 1969. A Note on the Job Satisfaction of Accountang in Large and Small CPA Firms, Journal of Accounting Research, Vol 7No. 2 pp 339- 345

35. Thorlakson Alan J.H. \& Robert P. Murray, 1998, "An Empirical Study of Empowerment in the Workplace", Journal Group \& Organization Management, Vol. 21 No.1 pp: 67-83.

36. Trisnaningsih, S. 2004. Pengaruh Komitmen terhadap Kepuasan Kerja Auditor: Motivasi sebagai Variabel Intervening (Studi Empiris pada Kantor Akuntan Publik di Jawa Timur), Jurnal Riset Akuntansi Indonesia, Vol 6, No.2, Mei, 199-216.

37. Wicaksono, 2008. Pentingnya Sebuah Keyakinan Diri.

38. Wright TA, Hobfoll SE., 2004, Commitment and psychological well-being and job performance: An examination of conservation of resources (COR) theory and job burnout. Journal Business Management, 9(4): 399-416. 